\title{
Southern Violence Revisited
}

\section{Citation}

Faust, Drew Gilpin, and Edward L. Ayers. 1985. "Southern Violence Revisited." Reviews in American History 13 (2) (June): 205.

\section{Published Version}

doi: $10.2307 / 2702411$

\section{Permanent link}

http://nrs.harvard.edu/urn-3:HUL.InstRepos:12008816

\section{Terms of Use}

This article was downloaded from Harvard University's DASH repository, and is made available under the terms and conditions applicable to Other Posted Material, as set forth at http:// nrs.harvard.edu/urn-3:HUL.InstRepos:dash.current.terms-of-use\#LAA

\section{Share Your Story}

The Harvard community has made this article openly available.

Please share how this access benefits you. Submit a story.

Accessibility 


\title{
SOUTHERN VIOLENCE REVISITED
}

\author{
Drew Gilpin Faust
}

Edward L. Ayers. Vengeance and Justice: Crime and Punishment in the 19thCentury American South. New York: Oxford University Press, 1984. ix + 353 pp. Appendix, notes, and index. \$24.95.

Edward Ayers has made a distinguished contribution to the venerable debate over the relationship between southerners and the laws. Perhaps even more important, however, his consideration of crime and punishment in the nineteenth-century South illuminates central questions concerning the character of the region in an era of fundamental change. Ayers's findings about rates and types of crime and patterns of conviction and punishment portray a distinctive section transformed by the experience of war and Reconstruction. Vengeance and Justice brings new evidence and a refreshing perspective to current disagreements about the "capitalist" or "precapitalist" nature of the Old South, about the ties between honor and slavery, about the effects of war and emancipation.

Ayers begins his study with a consideration of southern violence that allows him to characterize antebellum southern society more generally. Bertram Wyatt-Brown's recent work on honor occupies an influential place here, but Ayers has revised these earlier arguments to imbed honor in a social-structural context that he contends Wyatt-Brown neglected. "Slavery," Ayers asserts, "generated honor" (p. 26), and honor, in turn, produced violence and a sense of the limited applicability of law. An "overweening concern with the opinions of others" (p. 19), honor is in Ayers's view the product of economically undiversified, localized, explicitly hierarchical societies "where one standard of worth can reign" (p. 26). Slavery insulated the Old South from the market development and cultural diversity associated with capitalism and its system of values. In the North and other more developed areas, honor came to be supplanted by dignity, an internal rather than external gauge of self-worth - "the conviction that each individual at birth possessed an intrinsic value . . . theoretically equal to that of every other person" (p. 19). The importance of self-control, discipline, and autonomy within the wider notion of dignity indicates its close connection to "the transformations 
of society and personality that accompanied the growth and development of capitalism" (p. 24).

But Ayers does not portray the Old South as a monolith. Evangelical religion, for example, represented one important manifestation of the values of dignity in the region. More central to his concerns, however, is the penitentiary, the "archetypal institution of dignity, of internalized control" (p. 34), which paradoxically appeared in nearly every southern state before the Civil War. Yet Ayers's description of the penitentiary in the Old South casts it as the exception proving the rule of continuing southern distinctiveness. The prisons were usually built by southern leaders in spite of popular opposition, and they overwhelmingly housed individuals who were marginal within southern society - a disproportionate number of immigrants and urban dwellers, but few agriculturists of any kind, and almost no women or slaves. Penitentiary inmates, like the penitentiaries themselves, thus represented the inroads of capitalism into what still remained largely a precapitalist social order. The presence of such prisons in the South indicates that the region was changing, but their anomalous position demonstrates the embryonic nature of that incipient transformation.

Ayers particularizes his arguments about crime and punishment and about the changing character of the Old South by intensive examination of three sample communities, each representing an important southern subculture. Savannah serves as the locus for a discussion of urban crime, while Greene County, Georgia represents the rural black belt and Whitfield County the upcountry. In a quantitative anlaysis of local court records, Ayers finds sharp differences between rural and urban areas, with property crime far more significant in Savannah, as well as increasingly tied to swings of depression in the market economy. By the time of the economic downturn of the late 1850s, he discovers, enough city dwellers were dependent upon the vicissitudes of the market economy to spawn a crime wave that did not appear in Georgia's largely self-sufficient rural areas. Urban criminals tended to be outsiders; rural lawbreakers were most often locals arrested for crimes of violence. Yet these differences within the region did not override the continuing distinctiveness of the South as a whole: "Southern cities, which shared so much with their Northern counterparts . . . still harbored a markedly different configuration of crime, one marked by a higher percentage of violence" (p. 99). Ayers suggests a continuum of crime that parallels a continuum of economic and especially market development, with the urban North at one end, the rural South at the other.

Slaves occupied a small place within the official system of justice, for they were left largely to their owners' control or to the discipline of the whitedominated churches to which they frequently belonged. Ayers corroborates 
earlier scholars' findings that in their rare encounters with the courts, blacks were tried with apparent procedural fairness. But slavery itself served as the most significant form of regulation for blacks and the most important guarantor of order within society generally. "As long as slavery held the vast majority of the region's poor under rigid control, the South could afford a weak state, could afford to leave most white men alone, could afford to treat even accused criminals with leniency" (p. 137).

The Civil War was to bring "overwhelming change," and by the end of Reconstruction a new configuration of crime and punishment had emerged. As the state assumed control over blacks from their ex-masters, freedmen made up an ever-increasing proportion of those prosecuted and convicted under southern laws. And as the South moved more decisively into market agriculture, even rural areas began to display a significant rise in property crime. The economic crisis of the early 1870 s was clearly visible in rural as well as urban penitentiary convictions, thus underlying this growing market dependence. Increasingly, too, blacks became victims of discrimination within the legal system; white rates of conviction declined as black rates rose; blacks became the particular targets of the inhuman convict lease system, as well as of such extra-legal forms of control as the Ku Klux Klan. The nature of white hegemony, Ayers argues, had changed dramatically from prewar years when planter leaders had struggled to establish their authority and legitimacy as well as their power. Procedural fairness and the enlightened philosophy that had informed the penitentiary movement were abandoned as whites turned to more direct forms of compulsion in an effort to retain control over the newly freed black population.

Ayers treats the convict lease system at some length, for just as the penitentiary embodied the peculiar mix of old and new that characterized the antebellum South, so the evolution of convict leasing, arising from "both the heritage of slavery and the allure of industrial capitalism" (p. 192), represented postwar confusion. Employed in such enterprises as mines and railroads, convicts provided a source of all too scarce labor. "The New South," he concludes, "was no less an anomaly, no less an unstable mixture of contradictory elements, than the Old South had been" (p. 222).

By the last decade of the century, Ayers finds the region to have been in a "crisis" most clearly visible in the rising trajectory of violence, lynchings, and incarcerations that began in 1889, peaked in 1893 and 1894, then slowly dissipated. Ayers links these events to the economic decline of those years, providing further support for his contention that southern social order became more and more closely tied to national market vicissitudes as the century wore on. But, curiously, he denies deep political meaning to this violence and minimizes its links with the simultaneous rise of populism. When he char- 
acterizes the wave of criminality as a confrontation of local fears with changes introduced from outside, for example, a discussion of the meaning of the Lodge Bill of 1890 seems an almost unavoidable political parallel to the social issues on which he focuses. But he does not make the connection. "Political passions," he writes, "may have helped fuel the lynching crisis of the nineties by creating racial animosity, but overt political motives apparently accounted for little of the bloodshed" (p. 239). In such a statement, Ayers embraces a far too narrow notion of politics. Underlying the entire lynching phenomenon was a tacit political decision not to use the power of the state to halt these outrages.

Because crime is defined and prosecuted by the dominant classes within any society, it is necessarily a political phenomenon, reflecting and enforcing relationships of power. But Ayers shies away from directly exploring the relativism at the heart of the concept of crime. In his Introduction, he informs us that he has "defined crime broadly," but, in fact, he has not defined it at all. He has considered an enormous - and commendable - variety of "extrajudicial," as well as explicitly illegal behaviors, together with the broad range of social responses to them; Ayers includes within his analysis not only crimes tried in southern courts, but duelling, slave theft, violations of church discipline, wartime bread riots, postwar race riots, Klan violence, lynching, and "whitecapping." Yet this very inclusiveness underlines a confusion at the heart of his book. Ayers is to be admired for eschewing a narrow consideration of crime as defined by the actions of the South's formal legal system. But in going beyond such a narrow and hegemonic definition, he has introduced a certain imprecision.

As an inherently political notion, crime exists less in objective reality than in the eye of the beholder, as the abrupt appearance of "vagrancy" as a characteristic crime of the postwar South makes clear. No behavior is in itself criminal; it is, rather, interpreted as such by a social group exercising power in this very act of definition. Killing is honorable under some circumstances, indictable under others. But Ayers fails to address this interpretive dilemma. The categories of behavior he has chosen to examine lack conceptual logic or underlying coherence, for while some are defined by the nineteenth-century white South's legal system, others are, as Ayers himself admits, simply disruptive actions that in some unspecified way "mattered a great deal to large numbers of nineteenth-century Southerners" (p. 5). But not enough for the actions to be labelled and prosecuted as crimes. This juxtaposition of notquite-comparable actions results in a fundamental confusion about what Ayers intends by "crime," and produces an ironic, because unacknowledged, demystification of the entire concept.

As Ayers presents them, nineteenth-century southern crime and punishment often appear indistinguishable. The Klan's behavior clearly seems 
criminal to us, but its members believed they were engaged in justified actions of punishment. Similarly, a slave's theft of his master's property or violence against his master's person appeared as crime to whites, but may have been designed as a form of well deserved retribution by the slave. And is the murderous convict lease system more accurately characterized as crime or punishment? Both because his evidence implicitly exposes so many of these ironies and because his definition of honor at the outset of the book is of such exemplary lucidity, one wishes all the more that Ayers had grappled with the vexing notion of crime head-on, directly addressing rather than simply demonstrating its subjectivity, and thus making inescapably clear its connection to issues of politics and power.

During Reconstruction, Ayers acknowledges, "the boundary between political violence and criminal violence often disappeared" (p. 238). Yet one of the striking features of criminality in the nineteenth-century South is how tenuous that boundary was in the first place. Southern crime was not just disproportionately violent crime, as so many scholars have pointed out, but violence committed by individuals as self-conscious representatives of social groups - as lynchers, or Klan members, or even duellers, all preserving, as antebellum South Carolinian J. Marion Sims once put it, "the proprieties of society." A significant part of the distinctiveness of southern crime lies in this very reality. Far from being antisocial in its intentions, this sort of violence was meant, more like conventional notions of punishment than of crime, to enforce social norms. A considerable portion of southern lawlessness served as an essential prop to the status quo, rather than any sort of challenge to existing structures of power.

Ayers gives particularly short shrift to the foremost nineteenth-century example of the merging of political power with violence in defense of the status quo: the Civil War itself. If, as seems axiomatic, war in large measure reflects the society which produces it, the Old South's resort to arms in 1861 necessarily grew out of the region's perceptions of the place of violence and punishment within the social and moral order. Yet the wartime situation also changed the configuration and definition of crime in significant ways beyond the organization and sanction of mass murder. What was the social, legal, and ideological place of new "crimes" like desertion, which was often punished, or speculation, which usually was not? What about the actions of disloyal yeomen whose guerilla tactics would be considered simple lawlessness outside a wartime context? How did the existing legal system respond or not respond - to these realities, and what was the political and ideological framework within which this response was fashioned?

Edward Ayers has drawn a newly complex and compelling portrait of change and continuity in the nineteenth-century South. But like every important book, his has posed questions that remain unanswered. Crime, punish- 
ment, and politics are all ultimately concerned with the exercise of power. They cannot be considered apart from one another, especially in a society where justice and power have so often been on opposite sides.

Drew Gilpin Faust, Department of American Civilization, University of Pennsylvania, is the author of James Henry Hammond and the Old South: A Design for Mastery (1982). 